\title{
РОЗВИТОК ТРУДОВОГО ПОТЕНЦІАЛУ В СИСТЕМІ ЕФЕКТИВНОГО МЕНЕДЖМЕНТУ ОРГАНІЗАЦІї
}

\section{DEVELOPMENT OF LABOR POTENTIAL IN THE SYSTEM OF EFFECTIVE MANAGEMENT OF THE ORGANIZATION}

\author{
Зось-Кіор Микола Валерійович \\ доктор економічних наук, профресор, \\ Полтавська державна аграрна академія \\ ORCID: https://orcid.org/0000-0001-8330-2909 \\ Ільїн Валерій Юрійович \\ доктор економічних наук, профресор, \\ Київський національний економічний університет \\ імені Вадима Гетьмана \\ ORCID: https://orcid.org/0000-0002-4223-1865 \\ Свирида Еріка Олександрівна \\ здобувач вищої освіти, \\ Полтавська державна аграрна академія \\ ORCID: https://orcid.org/0000-0003-1288-5873 \\ Zos-Kior Mykola \\ Poltava State Agrarian Academy \\ Ilin Valerii \\ Kyiv National Economic University named after Vadym Hetman \\ Svirida Erica \\ Poltava State Agrarian Academy
}

\begin{abstract}
В статті узагальнено особливості розвитку трудового потенціалу в системі ефективного менеджменту організації. Виділено основні фрнкції менеджменту трудового потенціалу. Узагальнено основні фрункції менеджменту трудового потенціалу та методи забезпечення реалізації даних фрункцій. Узагальнено способи матеріальної та нематеріальної мотивації працівників. Наголошено на можливості застосування на практиці методу аутплейсменту та методу «підвищення вимог» при необхідності звільнення персоналу. Поєднання різних класичних та сучасних методів, які необхідні для реалізації функцій менеджменту персоналу, дозволяють отримати найбільш точні дані про особистість та її професійні якості з метою якісного відбору потенційних кандидатів. Використання даних методів розвитку персоналу дозволяє співробітниками отримувати нові навички які можуть їм знадобитися у випадку виникнення нестандартних бізнесситуацій.
\end{abstract}

Ключові слова: розвиток, трудовий потенціал, система, ефективний менеджмент, організація.

В статье обобщены особенности развития трудового потенциала в системе эффективного менеджмента организации. Выделены основные функции менеджмента трудового потенциала. Обобщены основные фрунции менеджмента трудового потенциала и методы обеспечения реализации данных фрункций. Представлены способы материальной и нематериальной мотивации работников. Отмечено возможности применения на практике метода аутплейсмента и метода «повышение требований» при необходимости увольнения персонала. Сочетание различных классических и современных методов, которые необходимы для реализации фрунций менеджмента персонала, позволяют получить наиболее точные данные о личности и ее профессиональные качества с целью качественного отбора потенциальных кандидатов. Использование данных методов развития персонала позволяет сотрудниками получать новые навыки, которые могут им понадобиться в случае возникновения нестандартных бизнес-ситуаций.

Ключевые слова: развитие, трудовой потенциал, система, эффективный менеджмент, организация. 
The article summarizes the features of labor potential development in the system of effective management of the organization. Since the haste of business does not depend so much on equipment and technology as on labor potential, the research topic is quite relevant. The main research methods are monographic and abstract-logical. Among the results obtained are the following. The main functions of labor potential management are highlighted: personnel needs planning, selection, hiring of personnel and formation of personnel reserve; staff training and evaluation; social guarantees and social package, creating a comfortable microclimate in the team; effective use of creative and labor potential of employees; development and implementation of strategic and tactical goals; analysis of available human resources, planning of its development; staff motivation. The main functions of labor potential management and methods of ensuring the implementation of these functions (interview; questionnaire; resume; exclusive search; head hunting; screening; E-recruitment; mass recruitment; outstaffing; preliminaring; brainteaser interview; physiognomy; shock interview) are summarized. The methods of personnel development (case-training, secondment, sahadowing, budding, basketball-method) are updated, the methods of material and intangible motivation of employees are generalized, the possibilities of application of outplacement method and method of "increasing requirements" in case of staff dismissal are emphasized. labor potential can be defined as a process carried out by managers and associated with the effective use of personnel, and as an activity aimed at the efficient use of human resources of the organization. the most accurate data $n$ personality and its professional qualities in order to qualitatively select potential candidates. To achieve the greatest effect, it is recommended to combine methods of tangible and intangible motivation. The use of these methods of staff development allows employees to gain new skills that they may need in case of non-standard business situations.

Keywords: development, labor potential, system, effective management, organization.

Постановка проблеми. В продовж майже всієї історії існування людства, ще уперіод розквіту перших цивілізацій, фрілософи постійно замислювались над особливостями раціонального управління людськими ресурсами. Починаючи від часів промислової революції почали зароджуватися перші наукові підходи щодо менеджменту персоналу. Погляди різних науковців та підприємців постійно змінювалися. Із розвитком науки менеджменту все більше дослідників починали наголошувати на важливості раціонального використання людського ресурсу. Практика показала що успішність бізнесу не скільки залежить від техніки та технології скільки від трудового потенціалу.

Аналіз останніх досліджень і публікацій. Менеджмент трудового потенціалу має свої певні фрункції, які являють собою фрактичні дії, а також систему організаційних, адміністративних та соціально-психологічних методів, за допомогою яких здійснюється управління людськими ресурсами організації. Виділяють такі основні фрункції менеджменту трудового потенціалу: планування потреби в кадрах, підбір, наймання персоналу та формування кадрового резерву; навчання та оцінка персоналу; соціальні гарантії та соціальний пакет, створення комфортного мікроклімату в колективі; ефрективне використання творчого та трудового потенціалу співробітників; розробка та реалізація стратегічних та тактичних цілей; аналіз наявного кадрового потенціалу, планування його розвитку; мотивація персоналу [6]. Для того щоб забезпечити реалізацію даних фрункцій, використовуються певні методи. На етапі створення та в процесі існування орга- нізації одним із найважливіших завдань є підбір персоналу [8]. В цілому підбір персоналу являє собою систему цілеспрямованих дій із залучення на роботу кандидатів, що володіють якостями, необхідними для досягнення цілей, поставлених організацією [2]. Розглянемо особливості розвитку трудового потенціалу в системі ефрективного менеджменту організації.

Виділення невирішених раніше частин загальної проблеми. В сучасних умовах розвитку економіки України із суттєвими змінами до якісних характеристик персоналу важливим і недостатньо дослідженим питанням $€$ питання підбору персоналу як складової розвитку трудового потенціалу.

Формулювання цілей статті (постановка завдання). Метою статті $€$ узагальнення особливостей розвитку трудового потенціалу в системі ефрективного менеджменту організації.

Виклад основного матеріалу дослідження. Виділяють такі основні фрункції менеджменту трудового потенціалу: планування потреби в кадрах, підбір, наймання персоналу та фрормування кадрового резерву; навчання та оцінка персоналу; соціальні гарантії та соціальний пакет, створення комфортного мікроклімату в колективі; ефрективне використання творчого та трудового потенціалу співробітників; розробка та реалізація стратегічних та тактичних цілей; аналіз наявного кадрового потенціалу, планування його розвитку; мотивація персоналу. Для того щоб забезпечити реалізацію даних фрункцій, використовуються певні методи. На етапі створення та в процесі існування організації одним із найважливіших завдань $€$ під- 
бір персоналу [1]. В цілому підбір персоналу являє собою систему цілеспрямованих дій із залучення на роботу кандидатів, що володіють якостями, необхідними для досягнення цілей, поставлених організацією. Розглянемо сучасні та класичні методи підбору персоналу які використовуються в практиці організацій.

Найбільш розповсюдженими класичними методами підбору є:

1. Співбесіда - $є$ одним із найбільш відомих та найрозповсюдженіших методів підбору персоналу [3]. $€$ популярним завдяки можливості отримання найбільш точної інформації про кандидата. Як правило проходить фрормі бесіди формату питання-відповідь. Тобто HR задає певні питання, що необхідні для прийняття рішення про прийом на роботу, а кандидат відповідає на них. Інколи до співбесіди може залучатися психолог, з метою аналізу психологічного портрету.

2. Анкетування - полягає в тому, що кандидатами надаються анкети 3 переліком питань із варіантами відповідей або/з розгорнутими відповідями. Даний метод дозволяє опитати одразу декількох претендентів [4]. Проте для отримання найбільш точного результату спочатку необхідно правильно сорормувати питання.

3. Резюме - подання кандидатом документа із стислою інсрормацію про свою трудову діяльність, освіту, професійні навички тощо [7]. Даний метод застосовується як допоміжний, адже аналіз за яким приймається остаточне рішення здійснюється під час співбесіди.

Перелічені вище методи активно використовується багатьма підприємствами. Проте умови сучасного середовища зумовлюють необхідність використання більш сучасних методів підбору персоналу. Серед сучасних традиційних методів варто виділити:

1. Exclusive search (ексклюзивний пошук) в деяких джерелах зустрічається під назвою «executive search», даний метод передбачає підбір Топ-менеджерів та керівників середньої ланки або спеціалістів рідкісних чи унікальних профресій [4]. Підбір здійснюється шляхом пошуку претендентів як серед «активних» кандидатів, тобто тих що шукають роботу, так і неактивних які вже працюють у конкурентів. Часто передбачає переманювання потрібних співробітників із організацій-конкурентів, шляхом створення мотиваційного пакету який би міг зацікавити претендента.

2. Head hunting - являє собою пошук ключових та рідкісних, як за фрахом, так і за рівнем профресіоналізму фрахівців [3]. Передбачає переманювання із інших організацій спеціалістів, які часто являються «зірками» у своїй ніші. Часто в процесі пошуку персоналу хедхантінг стає новим форматом ексклюзивного пошуку, або доповнює його.

3. Скринінг - використовується тоді, коли потрібно швидко відібрати претендентів за певними фрормальними ознаками, такими як: освіта, приблизний досвід роботи, вік, стать тощо. В середньому скринінг проводиться протягом 10-ти днів [6]. Даний метод є корисним для підбору персоналу нижчої ланки: секретарів, рядових бухгалтерів, продавців-консультантів, операторів колл-центрів, водіїв тощо.

4. Е-рекрутинг (циорровий рекрутинг, digital рекрутинг, електронний рекрутинг) - ефективний метод підбору персоналу з використанням інтернет-ресурсів, відмінною особливістю якого $€$ автоматизація всіх етапів роботи із потенційними кандидатами на робочі місця від відкриття вакансії до прийому співробітника на роботу [3].

5. Масовий рекрутинг - застосовується у випадку коли потрібно підібрати персонал на однотипні вакансії і головним завданням $€$ короткий термін пошуку [5]. Основним пріоритетом $\epsilon$ не якість а кількість. Тобто кваліфікація кадрів $€$ питанням другорядним. Таким чином підбирають фрахівців лінійного рівня (торгових агентів, рядових виконавців, секретарів тощо) .

6. Аутстафрінг - надає можливість використання робочої сили іншого підприємства. Даний процес полягає у виведені персоналу за штат організації-замовника та оформлення його у штат організації-провайдера [3]. Тобто працівники формально працевлаштовані в організації-провайдері, але можуть одночасно працювати і в попередній компанії.

7. Preliminaring - передбачає залучення перспективних випускників університетів, а також студентів старших курсів, як на постійну роботу так і на умовах тимчасового стажування в організації [2]. Такий процес можна назвати «омолодженням» організації, адже часто поява молодих і креативних працівників сприяє появі нових і нестандартних ідей.

Варто виділити такі нетрадиційні методи відбору персоналу як:

1. Brainteaser інтерв'ю - даний метод допомагає визначити рівень креативності кандидата та його вміння мислити нестандартно [8]. Претенденту дається невелика задача на логіку, або він повинен відповісти на «хитромудре» питання, яке ніяк стосується теми розмови. 
2. Фізіогноміка - передбачає вивчення рис обличчя та міміки претендента [1]. При аналізі цих характеристик визначається тип особистості кандидата, що допоможе зрозуміти чи підходить він для певної роботи.

3. Шокове інтерв'ю - застосовується, тоді коли одними із основних критеріїв відбору $€$ стресостійкість. HR-менеджер спеціально створює несподівані та неприємні ситуації для кандидата, наприклад, може залишити його в кабінеті самого на тривалий час, поставити провокаційні питання або інсценувати втрату резюме [3].

Невід'ємною фуункцією менеджменту трудового потенціалу $€$ розвиток та навчання персоналу [5]. 3 розвитком науки менеджменту 3'явилося багато успішних методів розвитку персоналу таких як: кейс-навчання, secondment, sahadowing, budding, баскет-метод.

Також невід'ємною фрункцією менеджменту персоналу є мотивація [5]. Під мотивацією в менеджменті варто розуміти процес стимулювання самого себе та інших на діяльність, направлену на досягнення індивідуальних та загальних цілей організації [2]. Методи, що використовуються для мотивації залежать від її видів [8]. Існують різні варіанти класифрікації мотивації персоналу [2]. Проте найбільш доцільно поділяти мотивацію на матеріальну та нематеріальну. Як відомо, відповідно до піраміди Абрахама Маслоу одними 3 первинних та найважливіших потреб людини $€$ фрізіологічні [4]. Задовольнити дані потреби людина може отримуючи матеріальну винагороду, тому спочатку варто розглянути саме матеріальну мотивацію. Матеріальна мотивація передбачає використання таких засобів як: заробітна платня, премії, надбавки, бонуси за успішне виконання роботи тощо [6]. Розмір заробітної плати це майже перше на що звертає увагу потенційний працівник, коли шукає собі роботу. Тому матеріальну винагороду можна вважати одним із основних стимулів працівника до продуктивної праці. Проте як показує практика просто платити гідну заробітну плату співробітникам недостатньо. Одним із найважливіших завдань системи мотивації можна назвати поєднання цілей індивіда та організації [2]. Як відомо, основною ціллю будь-якої комерційної організації $€$ отримання прибутку та досягнення його постійного збільшення. Кожен працівник бажає отримувати велику зарплату та прагне іï̈ підвищення. Якщо працівник буде розуміти що із збільшенням прибутку збільшаться й надходження до фронду оплати праці то про- дуктивність його праці зростатиме [5]. Для цього можна розробити програму відповідно до якої певна частина надпланового прибутку буде розподілятися між працівниками, тобто залучити працівників до участі в прибутках [4]. Кошти варто розподіляти порівну незалежно від посади яку займає працівник, стажу роботи в організації та інших фракторів [6]. Нематеріальна мотивація може передбачати використання таких засобів як: публічне визнання досягнень співробітника, тренінги та курси підвищення кваліфікації, медичне страхування, залучення співробітників до участі в прийнятті важливих стратегічних рішень, корпоративні заходи, вдосконалення умов праці тощо [1]. Зазначений перелік далеко не $€$ вичерпним, адже розробка та впровадження нових методів нематеріальної мотивації повністю залежить від творчого мислення керівництва [5]. Досягти максимального есректу від мотивації можна лише завдяки поєднанню матеріальних та нематеріальних методів [2]. 3 приклади успішних світових компаній які змогли досягти успіху в мотивуванні співробітників.

Одним із найкращих мотиваторів серед світових компаній $€$ Google. Окрім високої зарплатні, яка перевищує 10 тис. доларів, працівники отримують унікальний комфрорт на робочих місцях. Усі офріси компанії були спроектовані кращими дизайнерами світу із врахуванням не тільки стилістики Google, a й національних пріоритетів [5]. Працівникам дозволено навіть працювати в кімнатах для відпочинку, а наради взагалі можуть проводитися в гамаках на даху корпусу. Для задоволення потреб співробітників тут є: спортивна зала, перукарня, невелика клініка, хімчистка, релаксаційні центри тощо [3]. Поблизу офрісу завжди можна знайти їдальню або кафре, де співробітники можуть безкоштовно скуштувати страви як європейської так і азіатської кухні.

Досить нестандартний спосіб мотивації розробили в компанії Apple. Кожного року співробітники отримують знижку в розмірі $25 \%$ на придбання музичних плеєрів iPod та планшетів iPad. Також кожні три роки працівники отримують знижку в розмірі 250 доларів на придбання iPad, або 500 доларів на покупку комп'ютера лінійки Мас. Крім того, співробітникам надається знижка в 50\% на купівлю програмного забезпечення. Можна сказати, що це $є$ доволі розумним та хитрим способом мотивації, адже таким чином Apple не тільки мотивує працівників, а й стимулює збут своєї продукції [2]. 
Таблиця 1

Методи звільнення працівників

\begin{tabular}{|c|c|}
\hline Методи & Характеристика \\
\hline Аутплейсмент & $\begin{array}{l}\text { Це комплекс послуг які надаються працівникам, що змушені залишати } \\
\text { підприємство в результаті скорочення або звільнення, спрямованих на те, } \\
\text { щоб допомогти колишнім співробітникам в пошуку нового місця роботи } \\
\text { або переорієнтації на ринку праці. Головною перевагою даного методу } \\
€ \text { пом'якшення процесу звільнення і як результат мінімізація можливих } \\
\text { негативних наслідків. }\end{array}$ \\
\hline $\begin{array}{l}\text { Метод } \\
\text { «Підвищення } \\
\text { вимог» }\end{array}$ & $\begin{array}{l}\text { Як відомо в кожній компанії є співробітники робота яких є недостатньо } \\
\text { едективною. Вони звикли до стандартних вимог та звикли не викладатися } \\
\text { на повну. Даний метод використовується, для того щоб такі люди втратили } \\
\text { інтерес до певного підприємства. Для початку рекомендується скликати } \\
\text { зібрання для того щоб оповістити працівників про те, що настали складні } \\
\text { часи і тепер всім необхідно працювати вдвічі ефективніше. Тим хто до цього } \\
\text { не готовий компанія надасть гарні рекомендації для того щоб вони змогли } \\
\text { знайти інше місце роботи. Є декілька шляхів реалізації даного методу. } \\
\text { Можна зробити систему показників преміювання більш жорсткою або } \\
\text { висунути більш жорсткі вимоги до якості роботи. }\end{array}$ \\
\hline
\end{tabular}

Джерело: за матеріалами [4; 5]

В процесі існування будь-якої організації настає момент, коли потрібно звільняти працівників. Причини можуть бути різними від банальної некомпетентності працівника до необхідності скорочення штату через кризові явища в організації. Для того щоб уникнути негативних наслідків від звільнення співробітника (судові процеси, псування HR-репутації звільненим працівником, розповсюдження комерційної таємниці) варто застосовувати певні методи звільнення працівників (табл. 1).

Отже, для забезпечення реалізації фрункцій менеджменту персоналу використовуються певні методи. На етапі створення та в процесі існування організації одним із найважливіших завдань $€$ підбір персоналу. За історію існування науки менеджменту постійно з'являлися нові методи підбору. Серед класичних методів підбору які використовуються і по сьогодення варто виділити: співбесіду, анкетування та резюме. Умови динамічного бізнес-середовища зумовили появу й більш сучасних методів. Проте це не означає, що старі методи варто відкласти в сторону та перейти до використання нових. Адже, наприклад такий метод як співбесіда часто $€$ незамінним та найбільш ефрективним. До того ж використання певних методів зумовлюється особливостями об'єкта пошуку, а також строками в які повинен бути укомплектований штат.
Методи, що використовуються для мотивації залежать від їі видів. Найбільш доцільною $€$ класифрікація мотивації на матеріальну та нематеріальну. Для досягнення найбільшого ефректу рекомендується комбінувати методи матеріальної та нематеріальної мотивації.

Висновки. Менеджмент персоналу можна визначити і як процес, який здійснюється менеджерами і пов'язаний із ефективним використанням кадрів, і як діяльність, що спрямована на еорективне використання людських ресурсів організації. Досліджено різні класичні та сучасні методи які необхідні для реалізації срункцій менеджменту персоналу. Представлено такі сучасні методи підбору персоналу як: exclusive search, head hunting, е-рекрутинг, масовий рекрутинг, аутстафрінг, preliminaring. Приведено такі нестандартні методи відбору кадрів як: brainteaser інтерв'ю, фрізіогноміка та шокове інтерв'ю, які дозволяють отримати найбільш точні дані про особистість та її професійні якості 3 метою якісного відбору потенційних кандидатів. Також було представлено сучасні успішні методи розвитку персоналу такі як кейснавчання, secondment, sahadowing, budding та баскет-метод. Використання даних методів дозволяє співробітниками отримувати нові навички які можуть їм знадобитися у випадку виникнення нестандартних бізнес-ситуацій.

\section{СПИСОК ВИКОРИСТАНИХ ДЖЕРЕЛ:}

1. Болотова О. О. Сутність організаційно-економічного забезпечення ефективності менеджменту персоналу. Управління розвитком. 2018. № 2(192). С. 119-125.

2. Гнатенко І. А., Кулікова Ю. Е. Перспективні напрями вдосконалення управління персоналом в організації. Науковий вісник Херсонського державного університету. Економічні науки. 2016. № 16. С. 55-58. 
3. Денисенко М. П. Особливості фрормування та оцінки трудового потенціалу підприємства в сучасних умовах. Агросвіт. 2017. № 6. С. 21-27.

4. Зось-Кіор М. В., Скидан С. В. Особливості мотивації персоналу в умовах нестабільного бізнес-середовища. Економічний фрорум. 2020. № 3. С. 143-148.

5. Маркина И. А., Зось-Киор Н. В., Сёмич Н. И. Развитие персонала в системе корпоративного таймменеджмента. Формирование организационно-экономических условий эффрективного ффункционирования АПК: сборник научных статей XII Международной научно-практической консеренции (Минск, 28-29 мая 2020 года). Минск : БГАТУ, 2020. С. 74-79.

6. Олексенко Р. І. Управління персоналом у сучасних умовах господарювання. АгроСвiт. 2018. № 14. C. $41-45$.

7. Терещенко Л. В. Розробка механізму забезпечення ефективності менеджменту персоналу в процесі організаційних змін. Інфраструктура ринку. 2017. № 9. С. 118-122.

8. Чавичалов І. І. Методи оцінки ефрективності управлінського персоналу підприємства. Інвестиції: практика та досвід. 2018. № 1. С. 41-44.

\section{REFERENCES:}

1. Bolotova O. O. (2018) Sutnist' orhanizatsiyno-ekonomichnoho zabezpechennya efektyvnosti menedzhmentu personalu [The essence of organizational and economic support for the effectiveness of personnel management]. Upravlinnya rozvytkom, no. 2(192), pp. 119-125.

2. Gnatenko I. A., Kulikova Y. E. (2016) Perspektyvni napryamy vdoskonalennya upravlinnya personalom v orhanizatsiyi [Promising areas for improving personnel management in the organization]. Naukovyy visnyk Khersons'koho derzhavnoho universytetu. Ekonomichni nauky, no. 16, pp. 55-58.

3. Denisenko M. P. (2017) Osoblyvosti formuvannya ta otsinky trudovoho potentsialu pidpryyemstva $v$ suchasnykh umovakh [Features of the formation and assessment of labor potential of the enterprise in modern conditions]. Ahrosvit, no. 6, pp. 21-27.

4. Zos-Kior M. V., Skidan S. V. (2020) Osoblyvosti motyvatsiyi personalu v umovakh nestabil'noho biznes-seredovyshcha [Features of staff motivation in an unstable business environment]. Ekonomichnyy forum, no. 3, pp. 143-148.

5. Markina I. A., Zos-Kior N. V., Semich N. I. (2020) Razvitiye personala v sisteme korporativnogo taym-menedzhmenta [Personnel development in the corporate time management system]. Formirovaniye organizatsionno-ekonomicheskikh usloviy effektivnogo funktsionirovaniya APK: a collection of scientific articles of the XII International scientific-practical conference (Minsk, May 28-29, 2020). Minsk: BGATU, pp. 74-79. (in Ukrainian)

6. Oleksenko R. I. (2018) Upravlinnya personalom u suchasnykh umovakh hospodaryuvannya [Personnel management in modern business conditions]. Ahrosvit, no. 14, pp. 41-45.

7. Tereshchenko L. V. (2017) Rozrobka mekhanizmu zabezpechennya efektyvnosti menedzhmentu personalu $v$ protsesi orhanizatsiynykh zmin [Development of a mechanism to ensure the effectiveness of personnel management in the process of organizational change]. Infrastruktura rynku, no. 9, pp. 118-122.

8. Chavichalov I. I. (2018) Metody otsinky efektyvnosti upravlins'koho personalu pidpryyemstva [Methods for assessing the effectiveness of management personnel of the enterprise]. Investytsiyi: praktyka ta dosvid, no. 1, pp. 41-44. 